\title{
Environmental Change and Modernization of Fishing Gear for Fishermen in Depok Beach, Bantul, Yogyakarta 1995-2010
}

\author{
Muhammad Sunandar Alwi ${ }^{1 *}$, Endang Susilowati ${ }^{2}$, dan Sutejo K Widodo ${ }^{2}$ \\ ${ }^{1}$ Student of Master of History, Department of History, Faculty of Cultural Sciences, Diponegoro \\ University Semarang \\ ${ }^{2}$ Lecturer of History, Department of History, Faculty of Humanities, Diponegoro University Semarang
}

\begin{abstract}
The purpose of this study is to analyze environmental changes and modernization of fishing gear for fishermen. This article identifies and evaluates several impacts of the implementation of modernization of fishing gear, particularly by taking a case study on the fishing environment of Depok Beach, Bantul, Yogyakarta. This research is categorized as maritime history research. This study uses the historical method with a sociological approach. The results of this study state that Depok fishermen have experienced several changes in their fishing gear. Those who used to use traditional fishing gear then use modern fishing gear. Characterized by the use of the engine as a means of propulsion of the boat which in turn causes the fishing range to be wider. The influence of modernization has changed the mindset of the fishing community of Depok Beach. In addition, the threat of abrasion is very dangerous for buildings around the coast. Abrasion that occurs is caused by strong waves. Strong waves occur due to gusts of wind from the Indian Ocean. The waves continuously erode the sediment on the beach. The scour will affect the land area and will also affect the reduced activity. The effect of abrasion on buildings is very dangerous and detrimental to the people of Depok Beach.
\end{abstract}

\section{Introducation}

Coastal areas are transitional areas of sea and land. This condition causes the coastal area to get pressure from various activities and phenomena on land and at sea. Phenomena that occur on land include abrasion, flooding and activities carried out by the community, namely the construction of settlements, clearing of forests for rice fields, construction of ponds and those that ultimately have an impact on the coastal ecosystem. Likewise, phenomena in the sea, such as tides, storm surges and so on. Other natural factors that also cause environmental damage are earthquakes and tsunami waves due to damaged coastal ecosystems so that there are no barriers to dampen sea waves.

*Corresponding Author : muhammadsunandaralwi@,gmil.com 
The threat of climate change impacts is now increasingly felt by fishermen and coastal communities and exists in coastal areas and small islands. The threat is marked by various natural disasters in various parts of Indonesia. Dahuri stated that one of the causes of changes in coastal ecosystems is uncontrolled economic activity and awareness of the importance of preserving natural resources in coastal areas, which is still low among actors. According to Helmi and Satria, the socio-economic impacts of fishermen due to changes in coastal ecosystems are decreased fish diversity, loss of substrate, livelihoods and decreased business opportunities. Environmental damage, both in coastal areas and on land on small islands, directly and indirectly, causes damage to fish habitat. Damage to the coastal ecosystem environment affects the socio-economic conditions of the local community, such as the loss of roads, settlements, land, and public facilities due to coastal abrasion. The impact of ecosystem changes poses a serious threat to the main source of income for coastal communities, which are generally fishermen. A number of problems of ecosystem change have an impact on fishery activities.[1]

The Depok Beach area is experiencing environmental damage at limits that are not maximal, which will be threatened by environmental damage such as coastal abrasion and the disappearance of marine life as a source of livelihood. In this condition, the people of Depok Beach have the freedom to make alternative choices that are used as a basis for thinking, making decisions, and taking action. The concrete actions taken by the people of Depok Beach are in the form of ecological adaptation.

Coastal areas are areas that are prone to damage due to human activities. Coastal areas have a greater chance of impacting environmental damage, which can change coastal characteristics. So there needs to be guidance for local communities on how to manage a sustainable environment. This shows that human activities and the environment are interrelated because they involve many human activities that will have an impact on the environment, economy, physical and social. Lack of management of coastal areas in the use of resources that are not appropriate, lack of environmental standards, and a lack of balance between activities and physical space causes more severe damage to coastal areas. This will have an impact on the economic conditions of people who depend on coastal resources and the sustainability of coastal areas.[2]

Broadly speaking, many communities on the south coast depend on the marine sector, although not all of them. There are still many people who do not leave the agrarian base. The reluctance of the people of the south coast not to exploit the potential of the sea is influenced by culture and beliefs about creatures that rule the southern sea, which is considered to be frightening figures. This happens to the fishing communities of the South Coast of Yogyakarta, where farmer groups switch to service activities for various reasons, and there is encouragement and support from outside. Due to various limitations in the surrounding environment on land (land and work), it requires the community to find an appropriate adaptation strategy pattern. In addition, job diversification is an alternative strategy to deal with this reality.[3]

Kusnadi stated that this kind of strategy occurs because people have to make ends meet. By involving wives and family members in looking for work. Available jobs are an option taken by the community to maintain their survival. [4] This situation is very evident in Depok Beach, where agricultural land is often submerged by water with high salt content or land that is often short of water in most areas in the coastal area of Bantul, Yogyakarta. In addition, the influence of the environmental change process. This is because the first process occurs (physiological) continuously in the people of Depok Beach so that the community will experience adaptation and habituation. Changes in the biotic and abiotic environment. Second, it is influenced by the psychological condition of the people of Depok Beach. This psychological change is marked by a change in the attitude of the Depok Beach community 
to react when they threaten the safety of their lives, property, and their families and are threatened with taking these ecological adaptation measures. This change in attitude will form the process of consciousness (cognition).

If seen, fishermen like the one above make capture fisheries on the South Coast of DIY different from generally the North Coast of Java. Most communities on the North Coast have a long history of engaging in service activities. Mashuri (1996) has reported in detail about the role of the fishery sector on the North Coast of Java in the period 1850-1940. Boomgaard (1989) has shown that the island's economy, in addition to being characterized by the agricultural sector, is also dominated by fisheries and shipping industries that are quite advanced (as the primary sector) which are generally spread across the North Coast of Java, such as Batavia, which is now Jakarta, Demak, Semarang, Surabaya, Jepara. , Rembang, Lasem, Gresik, Madura, Banten and Cirebon. [5]

Meanwhile, fishing activities in the sea as a source of livelihood for the people of the southern coast of Yogyakarta can be categorized as new. Capture fisheries activities on the South Coast of DIY began to develop in 1995 around Depok Bantul Beach, Yogyakarta. By catching fish in the sea, it is still done in a simple way. Fishermen come from communities around the coast of Depok, B Wrap, Sono and other hamlets located in Parangtritis Village. To get expertise at sea, they learn it from fishermen who previously have this expertise, in this case, the Cilacap and fishermen. Local fishermen in this area are often referred to as print fishermen. It is called this because the expertise they have at sea is the result of learning that is still ongoing for one generation. It is different from the skills of fishermen in the pantura, which have been passed down from generation to generation. The livelihoods of the people living in coastal areas are still traditional agrarian style, especially dominated by marine fisheries and agriculture sectors. They still think that there is still much they can do to generate income rather than being forced to go to sea during the big waves and the months leading up to famine. After all, the development of fisheries in the coastal area of Depok still has to be learned from the culture of the maritime community in order to develop the fisheries sector on the Depok coast. [6]

During its development, modernization entered the fishing community. The term modernization is an obscure term. But generally, modernization is used to show growth and change. One of the modernizations that occur in Depok Beach fishermen is their fishing gear. Fishing gear that was originally using traditional methods has changed to more modern fishing gear. However, it does not rule out the possibility that there are fishermen who use traditional fishing gear to this day, as for the types of fishing gear used by fishermen prior to the modernization of fishing gear. Fishermen using fishing rods are grouped into two groups, namely fishermen who use boats and those who do not. Fishermen who use boats to fish have a slightly wider coverage area and are equipped with 3-5 hooks. Meanwhile, fishermen who do not use boats only carry out limited fishing near the coast with one fishing line. Time to catch fish using this type of fishing rod is unlimited; in other words, it can be used in the morning, afternoon, evening, or night. [7]

In the development of fisheries on the coast of Depok, there is "The Cilacap Connection" between local fishermen and Cilacap fishermen. This strong relationship occurs because of the existence of a relationship between regions that need each other. Cilacap fishermen need new "fish fields" while local fishermen need fishing and fishing skills. Until now, the relationship is still well maintained. Both parties still respect each other and work together. Collaboration with Cilacap fishermen began around 1995. The number of Cilacap fishermen who came to Depok beach was around 60 people. Most of the boats operating on Depok Beach come from Cilacap; only six boats are from Depok. But now, only about 10 Cilacap fishermen are still permanent residents in the Depok beach area. This designation is given to migrant residents who work and live in an area with an identity that is still original 
to the area of origin. The Cilacap fisherman lives in one of the residents' houses located in the coastal area of Depok, free of charge. They return to Cilacap during the dry season, around June-July. At that time, they will look for side jobs. [8]

From the description above, the fishing community of Depok Beach has its own uniqueness to research. Studies on Depok Beach fishermen from the aspects of fisheries and marine science have been widely carried out. However, studies in historical science are still rarely studied. For this reason, the author tries to do a study from the point of view of historical research. Therefore, several research questions arise, namely 1.) How is the process of modernizing the fishing gear of Depok Beach fishermen in 1995-2010? 2.) How is the influence of fishing gear modernization on the fishermen's life in Depok Beach, Yogyakarta? 3.) How is the influence on the environment, and how is the adaptation strategy for fishermen in Depok Beach Yogyakarta?.

\section{Method}

This research is maritime history research. Maritime history examines issues concerning coastal communities, port development, production level relations, the service sector, and so on. This study uses a number of sources in the period 1995-2010. The historical method consists of four stages, namely heuristics (collection of sources), source testing (criticism), interpretation, and historiography (writing of historical stories). [9] Heuristics is the process of collecting data that is related to the problem under study. This stage is a step to explore and collect historical sources. Historical sources used in this study consist of primary and secondary sources. The primary sources used in this study were mainly oral sources obtained through direct interviews. Interviews were conducted with people who knew, experienced and had a role in the events that became the object of research, such as village officials, TPI managers, fisherman figures, and others. With so many informants being interviewed, a collective experience will be obtained that shows history. The secondary sources used in this study were obtained through a literature study of books, articles, and other relevant scientific works. Written sources in the form of books were obtained at the Regional Library and Archives, Bappeda, Bantul Fisheries and Marine Service, Bantul Fisherman Group, and so on. Written sources were also taken from mass media such as newspaper Kedaulatan Rakyat, Tribun Jogja, Suara Merdeka and online media. External criticism to obtain authentic sources and internal criticism to obtain credible sources. The third stage in historical research is interpretation. At this stage, objective accuracy is required, especially in terms of interpretation. As a historiographical work, this study is limited by its spatial scope covering Depok Beach, Yogyakarta. The temporal scope covers the period 1995-2010. In 1995, many Depok fishermen were using modern technology in the form of fishing gear and used fleets. This research ended in 2010 because, in that year, the use of fishing gear and boat fleets was widely used by fishermen.

\section{Results and Discussion}

\subsection{Geographic Location}

Beach is located in Depok Hamlet, Parangtritis Village, Kretek District, Bantul Regency, Yogyakarta. Geographically, Bantul Regency is located between $7^{\circ} 58^{\circ} 33^{\circ}$ South Latitude to $8^{\circ} 2^{\circ} 26^{\circ}$ Longitude and between $110^{\circ} 25^{\circ} 15^{\circ}$ East Longitude to $110^{\circ} 28^{\circ} 15^{\circ} \mathrm{West}$ Longitude, with the following boundaries. North: Donotirto Village Southside: Indian Ocean Westside: Tirgohargo Village Eastside: Selohadjo Village / Girijati Village. While 
Geographically Depok Beach is a lowland area with quite a lot of waters (beaches), Depok Beach area has an altitude of $25 \mathrm{~m}$ above sea level with an average slope of 2-15\%. Depok Beach itself also has a beach area of \pm 25 ha.

The location of the coast on Depok Beach, which is south of the equator and directly faces the Indian Ocean, causes the waves to have an angled direction pattern to the coastline. This is also influenced by the arrival of the wind and waves according to the current season. The wind speed at the site ranges from 2.1-5 m/ s. In August-September, the wind speed ranges from 3.33-10,094 m/s with a gradual change from N316oE-N340oE. The waves have a pattern of direction coming at an angle to the coastline in general. [10]

Breaking waves can generate currents that sweep the coastal plain between the shoreline and the berms at the front, with a distance of 3-5 m. The residual current of breaking waves accumulates in bays on the coast measuring 50-100 m long and 20-30 m wide. This current has a speed of $1-2 \mathrm{~m} / \mathrm{s}$, while the reverse flow has a speed of $1.5-2.7 \mathrm{~m} / \mathrm{s}$. The instantaneous wind speed at the measurement location ranges from 2.1-5 m/s. Waves that are on the coast at Depok Beach can cause abrasion to take place sporadically both at the time and point of formation. The wave activity produces a local bay-shaped coast. Waves and currents erode berms 3-5 meters from the shoreline. The wave energy is concentrated in these bays with varying speeds between 1-2.7 m/s and forms current turbulence, which amplifies the abrasion forces. Backflow(rip currents) carries the sediment of sand into the sea with a relatively large capacity and competence.

\subsection{Modernization of Fishing Tools for Fishermen}

That modernization does not only include changes in functional or technical systems from traditional to modern methods but also leads to changes in the human mindset. According to Arif Satria, fishing gear modernization is influenced by the diffusion of outsiders. [2] Modernization is not just a change in techniques from traditional to modern methods but also includes changes in the conditions of fishing communities, which in general can be said to have undergone a process of change in these two things. Changes in fishing gear, changes in types of fishing businesses and patterns of working relationships have undergone very significant changes. The process of change in the fishing business has played an important role in the socio-economic life of the fishing community.

Modernization in the field of fishing technology in Depok Beach was influenced by fishermen from Cilacap. Andon fishermen are fishermen's habit of conducting seasonal migrations to catch fish to locations far from their homes. The interaction of local fishermen with fishermen outside Depok Beach encourages technology adaptation. Based on the type of fishing gear since 1995, fishermen on Depok Beach are divided into two, namely modern fishermen or advanced fishermen and traditional fishermen. Modern fishermen are fishermen who operate fishing gear gill nets. The area of modern fishermen's fishing operation using fishing gear is gill net operated in offshore waters within 4 miles of line II, namely 3-7 miles from the lowest tide point. Traditional fishermen are fishermen who operate the types of trawl / draw net and hand line fishing operation area with a distance of about 1-3 miles on line I from the lowest tide point. [11]

After the motorization in 1995 made the fishing area expanded, which then developed so that the fishing gear also developed into gill nets, trammel nets, fishing rods and varnishes. Simple fishing gear such as krendet and eret nets are still used by fishermen today, especially for fishermen who do not own a boat or are crew members. Depok beach fishermen catch a fishing ground on line one, which is about four nautical miles. With the fishing fleet using a jukung boat with a capacity of 1 GT and using an outboard motor size 15 PK. The fishing gear used is the trammel net, gillnet and longline fishing net. Motorboats in these areas 
generally have an average length of $8 \mathrm{~m}$, depth and width of $1 \mathrm{~m}$, and are equipped with outriggers and outboard motors with a power of 15-25 PK. Fishing gear used includes gill nets, rollers, cranes, and fishing rods. The average trip duration is 5-6 hours, with the number of trips varying widely in each observation area with an average range of 150-180 trips/year. [12]

The boat is made of fibreglass with a total LOA length of about 9 meters, a draft of 0.9 meters and a width of 0.8 meters. There are 33 boats operating on the coast of Depok, with 21 boats still active at sea, while the rest are still less active. In operation, fishermen start to go to sea at 06.00 am and return to land around 11.00-13.00. with a long sea or one trip was ranging from 5 to 7 hours. Most go to sea once a day, and only a few fishermen go to sea again at night. Because going to the sea at night is done during the harvest season. In one boat, 2-3 people, one tekong helmsman, and 1-2 crew members, the number of crew members who help is adjusted to the needs. Sometimes one crew member is from a local community who learns to go to sea.

With boat ownership, most of them are from Depok and its surroundings, and so on, the boats belong to fishermen Andon Cilacap. The boats belonging to the community that operate can be divided into the owner's boat and the owner's own boat. The boat owner of the skipper is operated by cultivator fishermen, both of whom act as tekong and as crew. Meanwhile, the boats belonging to themselves are operated by fishermen who own boats that act as tekong and help from fishermen as crew.

The engine used is an outboard boat engine with the Suzuki and Yamaha brands with a power of $17 \mathrm{PK}$ and is made from a mixed gasoline engine. The price of fuel that has to be paid by fishermen is Rp. 500-100 more high than general public fuel. So that it takes tens of litres of fuel to go to sea, this is one of the considerations of fishermen when going to sea. The existence of SPDN with good management is expected to be realized in this area. In addition, the limited engine capacity and the size of the water waves have a real influence on fishing operations and the amount they get.

The total number of motorboats on the South Coast of DIY is 316 units, 168 units each on the South Coast of Gunungkidul, 112 units in Bantul, and around 36 units in Kulon Progo. The number of motorboats will increase during the fishing season (September-May) due to the large number of andon fishermen who catch fish around the DIY South Coast. Fishing gear used is gill net shrimp tremmel net and a longline fishing rod with the following specifications:

First, gill net fishing gear is a fishing gear used to catch medium size demersal and pelagic fish. The size of the mesh used ranges from 2-5.5 inches, which depends on the needs of fishermen but generally around ten pis. Both trammel net fishing gear is the fishing gear used to catch jerbung shrimp and small fish with mesh sizes ranging from 3-5 inches for outer nets and 2 inches for inner nets. The results obtained from the shrimp nets are used as bait for longline fishing gear. The three longline fishing gears are used to catch large pelagic fish such as tuna. The fishing line used is 0.7 in size in 1 longline package. The number of fishing rods is around 300 pieces, a minimum of up to 1200 pieces of fishing line maximum. The distance between 1 fishing line to another is around 4-5 meters by being operated by the boat.

Longline fishing gear and gill nets are used separately in fishing operations. This is tailored to the needs of fishermen during the fishing season. When fishermen use swamps, the fishing operation begins with the spread of the trammel net shrimp. The yield from the trammel net is used for swamp bait. Meanwhile, when gill net between gillnet and shrimp net is used separately as needed.

The fishing area of Depok waters is included in the Coastal Water Area (WPP) of Samudera Indonesia 12, which is located at latitudes $108^{\circ}-112^{\circ}$ East Longitude and $9^{\circ}-14^{\circ}$ LS. With a beach length of Lk. $13 \mathrm{Km}$, which is currently not optimal in exploration. 
According to Sudirman and Mallawa (2004), the fishing port is the port where fishing vessels depart or dock. According to the Department of Marine Affairs and Fisheries (DISKANLA), ports in Bantul Regency are included in class D ports, namely Fish Landing Base (PPI), with the following specifications:

a. Serving ships up to $10 \mathrm{GT}$ in size.

b. The number of fish landed is 10 tons/day or $2000 \mathrm{~kg} /$ year.

c. Serving fishing boats operating in coastal waters.

Most of the capture fisheries business uses jukung boats with engine land use of $15 \mathrm{PK}$ and a boat tonnage of 1-5 GT. The total number of boats in Bantul Regency is 103 units, with 23 units in the Sanden area, 44 units in the Sr signal area, and 45 units in the Depok area. Most fishermen use fishing rods for prawe (longline), trammel net, and gill net.

In its development, science and technology are needed in fishing activities. Some fishermen have used GPS as a tool to determine direction and location, but most fishermen still rely on a "mental map" or what they often refer to as an "estimate". The role of science and technology that has been implemented by Depok fishermen is the use of cellphones to access information provided by BMKG regarding wind speed, wave speed and other information so that it can help fishermen determine the time to go to sea and anticipate existing events. The last concept is the natural physical condition. Natural physical conditions describe the geographical conditions of the South Coast. According to several informants, the geographical conditions of the southern sea tend to be unfavourable because it has very large troughs and waves, which are a separate obstacle for fishermen because fishermen cannot easily sail. Therefore, the concept of this natural physical condition is one of the obstacles to the fishing community of Depok Beach.

\subsection{The Effect of Modernization on Society}

The fishing gear modernization in the Depok Beach fishing community consists of two major concepts, namely abstract and operational concepts. The abstract concept consists of the coastal economy, social cohesion and tradition. Activities at sea, trade and tourism are phenomena found on the beach. This is the uniqueness of Depok Beach. Depok Beach has a very complex phenomenon that is different from other beaches, which tend to only present natural beauty and fishery activities. Another unique thing that was found was the traditions and beliefs related to the south coast. Depok Beach fishermen are still preserving the local wisdom tradition, namely sea almsgiving, which is carried out once a year as a form of gratitude. Another belief that is still believed is Ratu Kidul as the ruler of the South Coast. The social phenomenon seen on Depok Beach is a very close kinship. A high sense of kinship creates a calm and safe atmosphere, as well as in terms of the division of labour. Each individual has their respective roles, both as boat drivers, fishermen, fish traders to people who work in the service sector. [13]

The fishing community has a network of relationships patron-client, a very strong, diverse one that covers many aspects of socio-economic life. This relationship is formed because of the consequences of the characteristics of the work as fishermen as well as environmental conditions and the nature of natural resources, which are the economic basis of fishermen's life. The characteristics of these characteristics are the availability of fishery resources that depend on seasonal fluctuations, the nature of fishery resources that move dynamically due to the influence of natural and environmental changes, and various risks that occur in fishing activities. The patterns of social relations patron-client between owner fishermen and labour fishermen are characterized by work relations and the exchange of economic resources. 
The relationship only consists of the skipper fishermen or boat owners with the crew. Work relations between fishermen are generally carried out based on the relationship of help, kinship, and trust between boat owners or landlords and workers. Such work relationships occur for modern fishermen as well as traditional fishermen. The relationship that exists between fishermen and fishermen is also established, namely the relationship between fishermen on Depok Beach. This relationship is also well-established because the fishermen always prioritize a fairly close kinship system between them. In daily interactions, both within the family and in the environment around the fishermen, they always behave both in terms of speaking and in determining attitudes. The relationship between fellow fishermen, especially when they are at sea, they also help each other if one of the fishermen needs help. In terms of fishing gear ownership, he also never fails to lend his fishing gear to traditional fishermen who do not have fishing gear to catch fish.

In terms of environmental cleanliness, if they do not go to sea, they will always keep their environment clean so that they are far from all kinds of diseases. Therefore, the traditional fishermen in Depok Beach can always survive in dire economic conditions. However, this has never damaged the relationship that has existed so far just because the family's economy is always classified as poor. The relationship that exists between fellow fishermen is also based on a sense of concern for fellow fishermen and also on the basis of a high sense of solidarity that has been instilled in them and also for their descendants.

The relationship between fishermen and migrant fishermen is very good because they are aware that fishermen are the ones who provide a source of income. Likewise, with fishermen, the migrants for them are people who also provide income to meet the daily needs of fishermen's families. For example, when a fisherman is at sea and after he has finished fishing or has finished catching fish, the fishermen immediately sell their catch to the newcomers who are waiting by the beach. Their catches can vary from fish, shrimp and crab, which prices also vary, but most of them only catch fish. After catching the fish, they immediately sell it to the toka with an uncertain income, at least IDR 15,000.00 / day. Even though the income is not sufficient, the fishermen are very happy. Sometimes Andon also gives additional money to the fishermen because they know that the income will not be enough to meet their family's daily needs. This is what makes the relationship between fishermen and toke always good, and there are never disputes or conflicts. The relationship that exists is blood-related. However, even if it is economical, they never see him as a brother or not.

They try to be professional so that something unwanted happens. In addition to the relationship that exists between fishermen and andon fishermen, there are also other relationships that exist for their livelihoods as fishermen, namely the relationship that exists between fishermen and owners of capital. For the fishermen on Depok Beach, the owner of the capital is the person who always helps in overcoming the difficulties they face, especially in terms of the economy. In overcoming difficulties, they always ask for help from capital owners to be able to lend all their fishing needs in order to carry out their daily activities, namely as traditional fishermen. The owners of capital here not only lend all equipment for fishing but also provide loans in the form of money.

The relationship between fishermen and capital owners is very good, and there has never been any conflict between them. This is due to the relationship that exists, namely between fishermen and owners of capital that are interrelated with one another, and each of them provides mutual benefits. This relationship makes the traditional fishermen on Depok Beach ease their burden if there are traditional fishermen who do not have the equipment to go to sea, but not all traditional fishermen on Depok Beach depend on their livelihoods to the owners of the capital. This relationship is the same as a patron-client relationship. In the pattern of the patron-client relationship, each actor has a role and obligation in accordance with the status they have, whether he is as a patron or as a client. The role of the patron has 
a dual role, namely the role of protector and the role of a broker (intermediary). They are seeing the role of the patron as a multi-role role, in addition to being an agent of modernization and as a social and economic reformer.

Not all traditional fishermen on Depok Beach have a low economy, which depends on the owner of the capital for their livelihood. The owner of the capital does not just provide assistance to fishermen but also has to provide their respective benefits in the form of part of the catch obtained to the owner of the capital in order to replace the loan and does not have to be in the form of money because the owner of the capital also knows how the condition of fishermen who go to sea only using simple equipment. To replace fishermen's loans, you don't have to replace them with money. This also happens even though the relationship between the fishermen and the owner of the capital still has a sibling relationship. As patrons act as protectors to provide protection against legal and illegal extortion from the ruling party, in addition, patrons also provide economic assistance in times of economic crisis, help when sickness and provide loans. [14]

Conflict or conflict is a social process in which individuals or groups have differences in terms of emotions, cultural elements, behaviour, principles, ideology, or interests with other parties. This difference becomes a dispute where the dispute can produce threats or physical violence. Conflict occurs when an individual or group tries to fulfil a goal by opposing the opposing party accompanied by threats or violence that can have a negative or positive impact. Differences in feelings and views will give birth to conflict. Sometimes in a relationship in society, both in work relations and in other social relationships, there can be feelings of dislike for others. This situation occurs because of the jealousy one feels towards another, which creates a feeling of dislike because this feeling is stored for a long time, and the person cannot endure it. Conflicts between fishermen on Depok Beach rarely occur because of the well-established togetherness between them, but conflicts have occurred between fishermen; these conflicts involve fellow fishermen who are on Depok Beach. [15] The conflict occurred because a fellow fisherman cut a fisherman's friend's net so that the net was torn into pieces. Then because of the problem, there was a fuss between the two parties.

From the above statement, it can be seen that conflicts can occur because of problems between one individual and another, such as what happened between the fishermen above. Conflict does not only occur because there are things you don't like at that moment, but conflicts can also occur when one party has harboured a dislike for the other person for a long time. The results of the interview above indicated that the conflict occurred because certain parties wanted to kill their livelihoods by destroying their fishing equipment. However, the conflict that occurred between the fishermen did not cause any physical damage, but the conflict slightly injured the good relations that had been established between fishermen who were on Depok Beach.

In a conflict, making contravention is a hidden mental attitude towards other people or against cultural elements of a certain group. This hidden attitude can turn into hatred but not into conflict or contention. A contravention is a form of a dissociative process characterized by symptoms of uncertainty about a person or a plan and hidden feelings of dislike, hatred, or doubt about a person's personality. Contravention has occurred between fishermen, even though it happened in secret, meaning that it was only felt by one party. The feeling of dislike of fishermen is often felt when their own friends get more fish than themselves. For example, jealousy occurs in friends who get more fish, but that doesn't matter. Then it becomes motivation so that we are more enthusiastic about fishing.

Dislike always arises when someone feels that they are unable to compete with others. However, the feeling of disappointment or dislike is not conveyed directly to the person he does not like but is only kept by himself or shared with someone who is closer to him. They realize that this feeling of dislike if magnified, will only make the problem bigger. Fishermen 
dislike also arises when the status of their fishermen is disputed, namely that between Andon fishermen (migrant fishermen) and native fishermen of Depok Beach are differentiated in receiving funds from the government for the development of fishing facilities located on Depok Beach. Only the original fishermen of Depok Beach can enjoy the funds from the government, while the Andon fishermen cannot enjoy it. For example, when there is a fund derived from the government for the development of fishing facilities, we as migrant fishermen have never felt the benefit of these funds even though it is clear that the funds are intended for the development of fishermen who are on Depok Beach.

The conventions that occur among the fishermen of Depok Beach rarely cause big problems for fishermen. They are very aware that they live together and are looking for a fortune together, so it can be said that the contravention they experience is temporary because they think it is not good if they dislike other fishermen just because of minor problems.

\subsection{Changes in the Environment of Depok Beach}

Abrasion Abrasion that occurs from year to year is caused by strong waves. The strong waves occur due to the gusts of the wind from the Indian Ocean. These waves continuously erode the sediments on the beach. Scouring will affect the land area and will also affect buildings near the coast. Abrasion also affects the reduction of activities on Depok Beach. The effect of abrasion on buildings is very dangerous and detrimental to the people of Depok. Depok Beach area's environment will decrease and be damaged from year to year due to the abrasion that occurs.

The abrasion that occurs in the coastal area of Depok Beach causes sediment to be carried away by waves causing changes in the coastline. Abrasions that occur in Depok can disrupt local economic activities. Abrasion on Depok Beach from year to year has caused several housing units and shops to disappear. Abrasion creates problems for ecosystems and settlements on the coast. The impact of abrasion, which directly affects the community, is in the social and economic aspects. Economic and social aspects are various aspects related to people's lives, including demographic conditions, health, education, housing, crime, socioculture, and household welfare. Economic and social aspects in the coastal area of Depok Beach are very supportive of the life of the surrounding community. The coastal area of Depok Beach is a well-developed tourist attraction. The development of Depok Beach is supported by the facilities and other support. The management and development of Depok Beach greatly affect the population in the community's economy. From year to year, population dynamics have decreased due to the impact of abrasion that has brought residents' houses and places to sell, so that it will have an impact on the socio-economic conditions of the community. The abrasion on Depok Beach has an impact on economic changes as seen from the shift in the economic structure of the coastal areas, namely from the primary sector to the tertiary sector, although the shift is still relatively small. [16]

In its development, changes in the Depok coastal environment are due to different assessments, understandings and understandings. The difference in the assessment, understanding and understanding of the community about the relationship between the people of Depok Beach and the coastal environment causes the environmental area to change the behaviour of the Depok Beach community, which takes place continuously and develops in the community's life. In this case, the ecological adaptation of the Depok Beach community in environmental conservation efforts is very evident from the start of physical contact between individual communities and the coastal environment, namely the use of the coastal environment as a coastal protector from abrasion, barrier to sea waves and also economically, socio-culture and as a controller. The preservation of biodiversity provided by the environment. This is marked by the emergence of a stimulus or stimulation from outside that 
is perceived by the people of Depok Beach, which is determined by experiences, habits, knowledge, attitudes and actions taken by the community because they are motivated by the assimilation of their (cultural) characteristics. [3]

This behaviour adjustment is due to individual access as a form of community response so that they can adjust themselves to their environment well. Then it is balanced with the ability to adjust to the individual's environmental conditions (adjustment). The impact of the success of the continuous or repeated adjustment behaviour experienced by the Depok Beach community can increase the ability to face the next stimulus and will also have the potential to experience a decrease in the level of tolerance which is manifested in saturation so that the Depok Beach community will experience a point critical which is caused by hopelessness, boredom, and can lead to feelings of helplessness, decreased performance to the lowest point. [17]

This is called ecological maladaptation because the people of Depok Beach do not have strong access and also a weak community response so that environmental conservation efforts will fail. This critical point can be avoided by the community by increasing the reciprocal relationship between the community and the environment, namely by increasing the function of each component of the social environment (stakeholder) and the environmental component. The ecological adaptation of the coastal communities of Depok Beach is closely related to the socio-economic, socio-cultural, technological mechanisms and the role of social organizations that develop in the community and the surrounding environment. The reciprocal relationship between the social environment and social organizations that develop in Depok Beach and the available environmental resources is more influenced by the renewal of the nature of the community in developing ecological adaptation strategies in environmental conservation efforts around the coast.

\section{Conclusion}

Every human being has different behaviour depending on how humans or individuals interact with their environment. In relation to the environment, human behaviour can determine the sustainability of environmental conditions. Environmental management behaviour aims to meet the needs of today's life without destroying or reducing the ability of future generations to meet their daily needs. The approach framework used in environmental management is an integrated approach in optimizing the utilization of coastal and marine resources. Modernization is a common thing for the progress of society. Modernization in the field of fishing technology in Depok Beach is influenced by fishermen from (andon) Cilacap. The interaction of local fishermen with fishermen outside Depok Beach encourages technology adaptation. Based on the type of fishing gear since the 1995s, fishermen on Depok Beach are divided into two, namely modern fishermen or advanced fishermen and traditional fishermen. Modern fishermen are fishermen who operate fishing gear gill nets. Traditional fishermen are fishermen who operate the types of trawl/trawl nets and hand lines. Modernization of fishing gear for Depok Beach fishermen has an impact on changes in work relations and changes in the fisherman's catch. The existence of modernization has led to striking changes in fishermen. The practice of profit sharing among fishermen was coloured by mutual suspicion between the crew and the skipper. ABK felt that the distribution of the results as unfair. According to the records of the crew members, the total weight of fish caught by the fishermen is greater than that of the skipper. Meanwhile, the skipper insisted that the operating costs recorded by the skipper were greater. This situation resulted in the crew taking fish before the totalan. 


\section{Acknowledgments}

In the preparation of this scientific research manuscript, the authors received assistance from various sources, for that the author would like to thank: ICENIS UNDIP 2021 and the Department of History of UNDIP and colleagues who have helped and guided writers for research. Finally, thanks are conveyed to all parties which cannot be mentioned one by one.

\section{References}

[1] A. Cahyadi, M. A. Marfai, S. H. Murti, H. Fatchurohman, and M. N. Malawani, "KARAKTERISTIK AKUIFER WILAYAH KEPESISIRAN PARANGTRITIS, KABUPATEN BANTUL," 2017, doi: 10.31227/osf.io/9j3xz.

[2] A. Helmi and A. Satria, "Fisher' s Adaptation Strategies to Ecological Changes Abstract," Makara Hubs-Asia, vol. 16, no. 1, pp. 68-78, 2012, doi: 10.7454/mssh.v16i1.1494.

[3] M. A. Mustafa and Y. Yudhicara, "KARAKTERISTIK PANTAI DAN RESIKO TSUNAMI DI KAWASAN PANTAI SELATAN YOGYAKARTA," J. Geol. Kelaut., vol. 5, no. 3, pp. 159-167, 2016, doi: 10.32693/jgk.5.3.2007.143.

[4] Kusnadi, "Budaya Masyarakat Nelayan,” Jelajah Budaya, vol. 1, no. 1, p. 9, 2010, [Online].

Available: http://repositori.kemdikbud.go.id/1066/1/Budaya_Masyarakat_NelayanKusnadi.pdf.

[5] S. Suadi, "FROM FARMERS BECOME FISHERS: A HISTORICAL STUDY OF SOUTH COASTAL YOGYAKARTA MARINE CAPTURE FISHERIES," $J$. Perikan. UGM (GMU J. Fish. Sci.) IV, vol. 4, no. 1, pp. 5-12, Jan. 2002, Accessed: Aug. 22, 2020. [Online]. Available: https://journal.ugm.ac.id/jfs/article/view/8869.

[6] I. Chairunnisa, R. Rijanta, and M. Baiquni, "Pemahaman Budaya Maritim Masyarakat Pantai Depok Kabupaten Bantul," Media Komun. Geogr., vol. 20, no. 2, p. 199, 2019, doi: 10.23887/mkg.v20i2.21216.

[7] Y. Witasari and Helfinalis, Sumber Daya Laut di Perairan Pesisir Gunungkidul, Yogyakarta. 2015.

[8] A. Rakhmanda, . S., and S. Supardi Djasmani, "Role of Fisher Group in The Fisheries Development in Sadeng Coast Gunungkidul Regency," Sodality J. Sosiol. Pedesaan, vol. 6, no. 2, 2018, doi: 10.22500/sodality.v6i2.23225.

[9] L. Gottschalk, "Mengerti Sejarah, terj," Nugroho Notosusanto. Jakarta Univ. Indones., 1986.

[10] Dewi Taukidah, Theresia Retno Wulan, A. N. Rochim, E. Maulana, and A. S. Putra, "Dampak Abrasi Terhadap Aspek Ekonomi-Sosial Masyarakat di Pantai Depok, DIY," Bunga Rampai Kepesisiran dan Kemaritiman Jawa Teng., vol. 2, no. April 2018, pp. 36-43, 2017.

[11] D. Sulistiyono, Suwarto, and M. G. Rindarjono, "TRANSFORMASI MATA PENCAHARIAN DARI PETANI KE NELAYAN DI PANTAI DEPOK DESA PARANGTRITIS KABUPATEN BANTUL," J. GeoEco, vol. 1, no. 2, pp. 234-249, 2015.

[12] A. B. M. Kamim, I. Amal, and M. R. K. Khandiq, "Pemerintah Sebagai Agen Perubahan Sosial Yang Direncanakan: Studi Atas Pembangunan Kemaritiman Daerah Istimewa Yogyakarta," Dialekt. Masy. J. Sosiol., vol. 2, no. 2, pp. 95-120, 2018.

[13] Q. Shen, "Robinson Crusoe's translation and spreading of marine spirit in premodern China," J. Mar. Isl. Cult., vol. 5, no. 1, pp. 1-4, Jun. 2016, doi: 10.1016/j.imic.2016.04.001. 
[14] D. Halim and Y. S. Susilo, "Faktor - Faktor Yang Mempengaruhi Pendapatan Masyarakat Nelayan Pantai Di Kabupaten Bantul Tahun 2012," J. ISSN Univ. Atma Jaya Yogyakarta, vol. 25, no. 2, pp. 171-187, 2013.

[15] Saraswati, "Pengelolaan dan Pendapatan Usaha Perikanan Laut Rumah Tangga Nelayan di Pantai Selatan Kabupaten Bantul," no. 4, pp. 1-16, 2014.

[16] Y. R. Freski and Srijono, "Mekanisme Abrasi Pesisir di Kawasan Pantai Depok, Bantul, Daerah Istimewa Yogyakarta," 2013.

[17] H. Pramono, "FISIOGRAFI PARANGTRITIS DAN SEKITARNYA," Geomedia Maj. Ilm. dan Inf. Kegeografian, vol. 5, no. 1, 2017, doi: 10.21831/gm.v5i1.14202. 